\title{
Role of macrofauna functional traits and density in biogeochemical fluxes and bioturbation
}

\author{
Ulrike Braeckman ${ }^{1, *}$, Pieter Provoost ${ }^{2}$, Britta Gribsholt ${ }^{3}$, Dirk Van Gansbeke ${ }^{1}$, \\ Jack J. Middelburg ${ }^{2}$, Karline Soetaert ${ }^{2}$, Magda Vincx ${ }^{1}$, Jan Vanaverbeke ${ }^{1}$ \\ ${ }^{1}$ Ghent University, Department of Biology, Marine Biology Section, Krijgslaan 281/S8, 9000 Ghent, Belgium \\ ${ }^{2}$ Netherlands Institute of Ecology (NIOO-KNAW), Centre for Estuarine and Marine Ecology, PO Box 140, 4400 AC Yerseke, \\ The Netherlands \\ ${ }^{3}$ Center for Geomicrobiology, Department of Biological Sciences, Aarhus University, Ny Munkegade, Building 1540,8000 \\ Aarhus C, Denmark
}

\begin{abstract}
The importance of different functional traits of macrobenthos in benthic processes of the Southern Bight of the North Sea was investigated to estimate the effects of density declines and species loss on benthic ecosystem functioning. Two laboratory experiments were performed: before (winter, temperature $=10^{\circ} \mathrm{C}$ ) and after (summer, temperature $=18^{\circ} \mathrm{C}$ ) sedimentation of the spring phytoplankton bloom. Single species treatments of key species (Abra alba, Lanice conchilega and Nephtys sp.) with different functional traits were added to microcosms at 3 density levels (natural, lower, lowest) to account for possible density declines. Sediment-water exchanges of oxygen and nutrients, denitrification and bioturbation were measured. In absence of fauna, benthic mineralisation in the summer experiment was 2.0 times higher than in winter. Fauna stimulated microbial respiration more in summer (up to $100 \%$ in L. conchilega treatments) than in winter (negligible fauna effect). As chlorophyll a concentrations were similar in both seasons, the stronger fluxes in summer must be explained by a higher macrobenthic activity owing to the elevated temperature and better condition of the animals. Stimulation of mineralisation by the 3 species in the microcosms was different, and behaviour-related. Owing to its irrigation activity, the tube dweller L. conchilega had more pronounced influences on benthic respiration, nutrient release and denitrification than did the biodiffusers, A. alba and Nephtys sp. A. alba appeared to be a more effective bioturbator than Nephtys sp. Processes such as benthic respiration, nutrient fluxes, denitrification and bioturbation seem to be related to animal densities and therefore decreases in densities can possibly have implications for ecosystem functioning.
\end{abstract}

KEY WORDS: Ecosystem functioning - Macrobenthos - Functional traits · Density - Temporal variability $\cdot$ Lanice conchilega $\cdot$ Abra alba $\cdot$ Nephtys sp.

\section{INTRODUCTION}

Macrofauna-induced particle mixing (bioturbation) and solute transfer (bio-irrigation) contribute extensively to ecosystem functioning in areas where physical disturbance is low (Kristensen \& Kostka 2005, Meysman et al. 2006). In search for food, macrobenthic organisms actively rework and irrigate the sediment. Oxygen and organic matter are transported deeper into the sediment and transfer of excretion products to the water column is enhanced. Furthermore, these organisms stimulate mineralisation (Yingst \& Rhoads 1980, Mermillod-Blondin et al. 2004), increase nutrient turnover and therefore renew the pool for primary production (Blackburn 1988).

Due to disturbance of the seabed, be it natural or anthropogenic, e.g. trawling (Bergman \& Hup 1992), dredging (Rhoads et al. 1978) and hypoxia (Van Colen 
et al. 2008) resulting from eutrophication or global warming, macrobenthos densities and community structure can change (Pearson \& Rosenberg 1978, Thrush et al. 2006). Removal of ecosystem engineers (organisms that influence the resources of other biota via changes in the environment; see Jones et al. 1994) such as bioturbators and bio-irrigators could induce large changes in the structure of the habitat, with cascading effects on local biodiversity (Coleman \& Williams 2002) and ecosystem functioning, such as benthic mineralisation processes (Olsgard et al. 2008, Rossi et al. 2008). Thus, it is of critical importance to study the role of species densities in ecosystem functioning (Marinelli \& Williams 2003).

Much progress has been made in describing the role of different functional macrobenthic traits in marine ecosystem functioning (Mermillod-Blondin et al. 2004, Michaud et al. 2005, 2006, Norling et al. 2007, Rossi et al. 2008). Several species have been recognized as ecosystem engineers (Vopel et al. 2003, Maire et al. 2007, Volkenborn et al. 2007), because of their mediating effects on biogeochemistry. There is, however, still a need for identifying the effects of other possible ecosystem engineering species on biogeochemical cycling. These case studies are necessary to provide basic material that can be integrated into the broad ecosystem engineering concept (Wright \& Jones 2006), which is important for conservation concerns. Some work has focused on the effects of macrobenthic density (e.g. Marinelli \& Williams 2003, Duport et al. 2006) on sediment-water exchange and sediment reworking, but few researchers have studied the effect of temporal variability (Ouellette et al. 2004, Maire et al. 2007).

The goal of this study was to extend the experimental work of the last decades by integrating different factors (functional traits, density and temporal variability) influencing ecosystem functioning. The study site, situated in the Belgian Western Coastal Banks, has been put forward as an area that deserves marine protection. The area is of high ecological value and is dynamic in terms of sediment metabolism (Van Hoey et al. 2004, Franco et al. 2007, 2008). Sedimentation of the spring phytoplankton bloom strongly influences biogeochemical gradients in the sediment and bioturbation is thought to be an important factor in structuring these patterns (Vanaverbeke et al. 2008).

To verify this hypothesis, the influence of 3 abundant species with functionally different traits on benthic ecosystem processes was assessed. Abra alba, a bivalve, reworks the upper layer of the sediment at random and is therefore called a biodiffuser (Gerino et al. 2003, Maire et al. 2007). Lanice conchilega, a tube building polychaete, acts as a piston pumper (Forster \& Graf 1995) and can occur in high density patches, referred to as reefs (Rabaut et al. 2009). These reefs host a wealth of associated species (e.g. Callaway 2006, Rabaut et al. 2007); therefore, L. conchilega is considered an ecosystem engineer of high functional value and in need for conservation (Godet et al. 2008). Both A. alba and L. conchilega are suspension-deposit feeding organisms. Nephtys spp. are predatory polychaetes that act as biodiffusers by creating transient burrows (Hartmann-Schröder 1996).

In the present work, single species treatments of each of the 3 species were incubated in 3 densities: (1) their natural density, (2) a lower and a (3) lowest density, to investigate the effect of possible density declines on benthic ecosystem functioning, as measured by sediment-water exchange rates of oxygen, dissolved inorganic nitrogen (DIN $=\mathrm{NH}_{4}{ }^{+}+\mathrm{NO}_{2}{ }^{-}+$ $\mathrm{NO}_{3}{ }^{-}$) and dinitrogen gas $\left(\mathrm{N}_{2}\right)$, (i.e. denitrification) and bioturbation. The influence of temporal variability was assessed by setting up 2 experiments, one performed in winter before the phytoplankton bloom deposition when macrobenthos was naturally starved, and one in summer when macrobenthos had been feeding on the large amount of organic matter (OM) deposited during and after the spring phytoplankton bloom. The null hypotheses of this study were that (1) the functional traits of the macrobenthic species, (2) density of the species and (3) temporal variability would not affect biogeochemical fluxes or sediment reworking.

\section{MATERIALS AND METHODS}

Field sampling. Sediment from the fine sandy coastal Stn 115 bis $\left(51^{\circ} 09.2^{\prime} \mathrm{N}, 02^{\circ} 37.2^{\prime} \mathrm{E}_{\text {; }} 13 \mathrm{~m}\right.$ depth) in the Western Coastal Banks area was collected in January and July 2007 with a Van Veen grab from the RV 'Zeeleeuw'. Characteristics of the benthic communities at Stn 115bis are given in Vanaverbeke et al. (2008) and van Oevelen et al. (2009). Sediment was defaunated by sieving over a $1 \mathrm{~mm}$ mesh, followed by freezing and thawing (Schratzberger et al. 2004), and stored frozen $\left(-20^{\circ} \mathrm{C}\right)$ for $6 \mathrm{wk}$ until the start of the experiment. This defaunation method eliminates macro- and meiofauna but does not eliminate bacterial populations (Stocum \& Plante 2006). The median grain size of the sediment was $185 \mu \mathrm{m}$ and consisted of $14 \%$ silt (van Oevelen et al. 2009). Pigment concentrations in water and sediment were determined in February and September. Water samples were collected with 101 Niskin bottles at $3 \mathrm{~m}$ below the water surface and $1 \mathrm{~m}$ above the sea floor. Three replicate samples of $500 \mathrm{ml}$ each were filtered onto GF/F glass microfiber filters. Sediment was sampled deploying a Reineck box corer $\left(180 \mathrm{~cm}^{2}\right)$. From 3 box corers, a Perspex core (inside diameter [i.d.] $3.6 \mathrm{~cm}$ ) was sliced in $1 \mathrm{~cm}$ hori- 
zons down to $5 \mathrm{~cm}$. Sediment and water pigment samples were preserved at $-20^{\circ} \mathrm{C}$ on board ship and stored at $-80^{\circ} \mathrm{C}$ in the laboratory on shore within $8 \mathrm{~h}$. Pigments (chlorophyll a [chl a], phaeophytin and phaeophorbid) were analyzed by HPLC (Gilson) as described by Wright \& Jeffrey (1997).

Natural densities of Abra alba, Lanice conchilega and Nephtys sp. in the study area reach up to 5000, 1000 and 300 ind. $\mathrm{m}^{-2}$, respectively (Degraer et al. 2006). A. alba and Nephtys sp. were collected with a Van Veen grab. L. conchilega is known to retract quickly into its tube upon disturbance and sampling with a Van Veen grab would have resulted in damaged animals (Van Hoey et al. 2006); therefore, we collected L. conchilega from the intertidal zone by means of metal frames (M. Rabaut et al. unpubl. data). In this way, dense $L$. conchilega blocks could be easily transferred to the laboratory. Animals were acclimatised in aquaria in their natural sediment with a continuous supply of fresh oxygenated seawater. After $1 \mathrm{wk}$, they were measured, blotted to determine wet weight and introduced in microcosms at defined densities (Table 1). L. conchilega was buried into the sediment within its tube as described by Ziegelmeier (1969) to avoid extreme stress. To check the fitness of the animals, the fringed tube end was cut after introduction to the sediment. The next day, all (except one in September) animals had rebuilt a new crown of fringes. A. alba and Nephtys sp. buried themselves within $<5$ min. As we worked with natural densities, because of the ecological relevance, densities and biomass differed among species treatments (Table 1). Twenty-one microcosms were attributed to the different treatments: 2 for each density of every species treatment (18 fauna treatments). Three defaunated controls were used to measure background fluxes and bioturbation.

Experimental set-up. The experiments were performed in a climate controlled room at the Netherlands Institute of Ecology, Yerseke. Plexiglas cores of $10 \mathrm{~cm}$ i.d. and $50 \mathrm{~cm}$ height with Teflon lids were filled with homogenised mixture of defaunated sediment and seawater in equal proportions (Fig. 1). These microcosms were submerged uncapped in an open tank with a continuous flow through of seawater (salinity 32 ) from the Oosterschelde at $10^{\circ} \mathrm{C}$ in March and $18^{\circ} \mathrm{C}$ in September. Teflon-coated magnets rotated by a central magnet were inserted approximately 10 and $20 \mathrm{~cm}$ above the sediment surface to ensure sufficient water mixing. The rate of water circulation was kept well below the resuspension limit. Microcosms were left to stabilise for $1 \mathrm{wk}$ in darkness before introducing the animals to allow development of a biogeochemical steady state.

Benthic flux measurements. The flux across the sediment-water interface of oxygen, DIN and $\mathrm{N}_{2}$ was determined 1 wk after introducing the organisms. All equip-

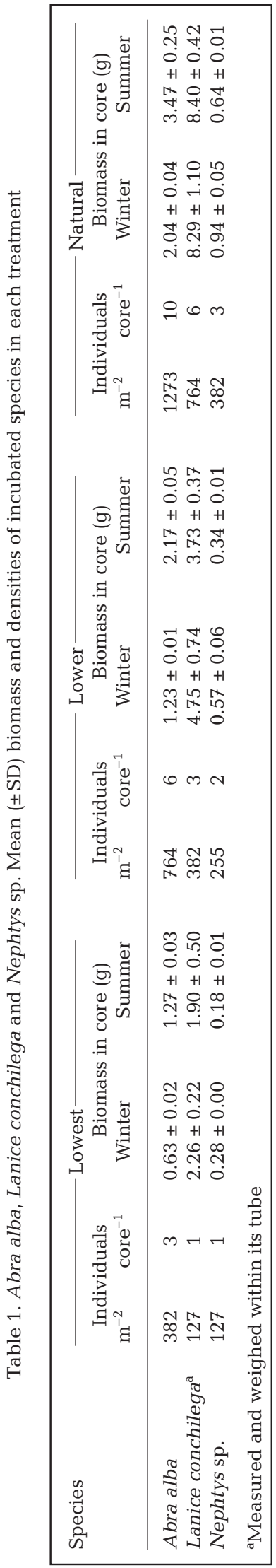




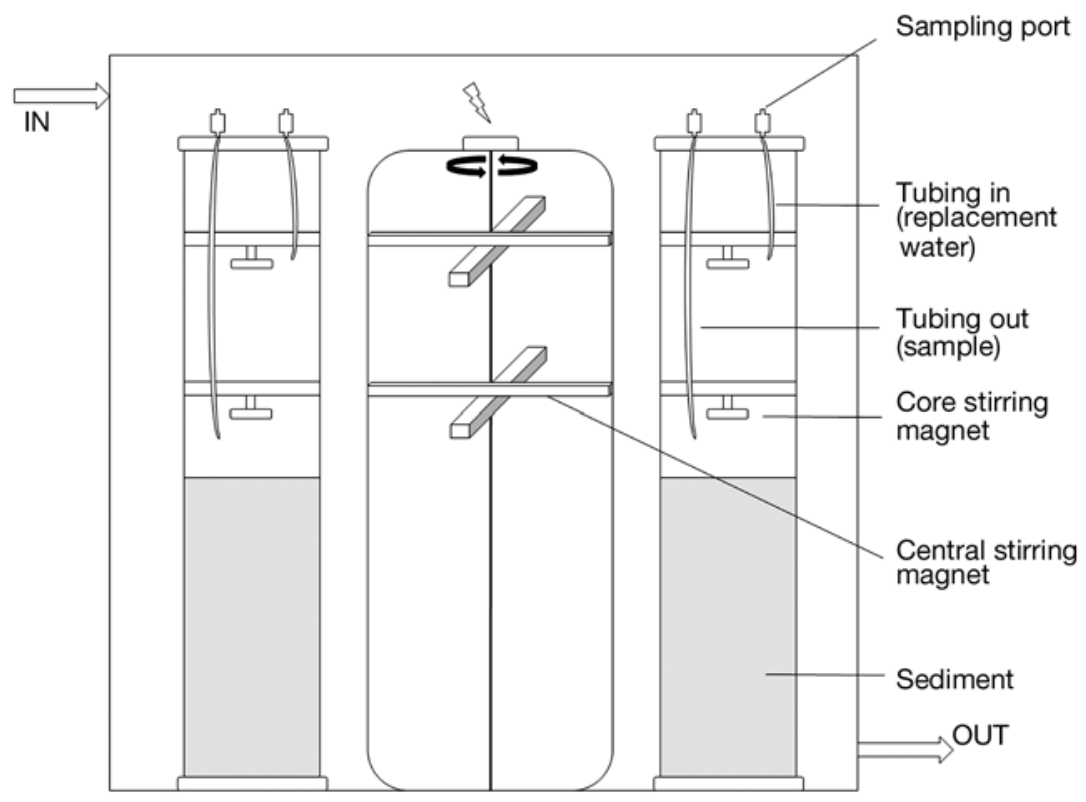

Fig. 1. Experimental set-up. Plexiglas cores submerged in a tank with continuous flowthrough of seawater from the Oosterschelde. Cores are shown as during flux measurements (capped)

ment used for the incubations (lids, Teflon tubings, Luer stopcocks) was submerged in the incubation tank $48 \mathrm{~h}$ before measurements were taken to avoid introduction of new surfaces for $\mathrm{O}_{2}, \mathrm{~N}_{2}$ and argon (Ar) adsorption. This is pivotal for the correct determination of $\mathrm{N}_{2}$ production (Kana et al. 1994). Each core was sealed with an airtight lid and incubated in darkness for $36 \mathrm{~h}$ (March) and $8 \mathrm{~h}$ (September), depending on the change in overlying water dissolved oxygen concentration, which never decreased below $50 \%$ air saturation.

Sample collection was performed as described in $\mathrm{Na}$ et al. (2008). The concentrations of $\mathrm{N}_{2}$ and Ar were determined by membrane-inlet mass spectrometry (MIMS) with an Omnistar QMS 200 quadrupole mass spectrometer (Baltzers Instruments). $\mathrm{N}_{2}$ and $\mathrm{O}_{2}$ concentrations were normalised to those of Ar (Kana et al. 1994) and the $\mathrm{N}_{2}$ production and $\mathrm{O}_{2}$ consumption calculated from the linear increase and decrease, respectively in Ar-normalised $\mathrm{N}_{2}$ and $\mathrm{O}_{2}$ concentration and corrected for refill water (Na et al. 2008). DIN samples were filtered through GF/F filters (Whatman), frozen immediately and analysed using automated colourimetric techniques. Net DIN fluxes were calculated from the difference between initial and final samples compensating for dilution by refill water. Vertical oxygen profiles (5 per core) were measured in September with oxygen microsensors (type ox25, Unisense) in vertical increments of $250 \mu \mathrm{m}$.

Bioturbation measurements. To estimate bioturbation activity of Abra alba and Nephtys sp., luminophores (Environmental Tracing Systems) were used as tracers for sediment transport. White and pink luminophores of the same size as the sediment median grain size $(180 \mu \mathrm{m})$ were placed as frozen mud cakes $(1.7 \%$ luminophores, $5 \mathrm{~mm}$ thickness) on the surface (white) and within the sediment column (pink, $4 \mathrm{~cm}$ depth) to investigate downward and upward transport, respectively (Gerino et al. 1998). After $14 \mathrm{~d}$, water was carefully siphoned off and cores were stored at $-20^{\circ} \mathrm{C}$. Cores were subsequently sliced in $5 \mathrm{~mm}$ sections down to $6 \mathrm{~cm}$ depth, then $1 \mathrm{~cm}$ sections to $10 \mathrm{~cm}$ depth. Image analysis of UV-illuminated pictures (Canon 350D digital SLR camera) of oven dried and carefully homogenised sediment sections resulted in vertical luminophore profiles. Bioturbation rates were calculated by fitting a non-local transport model to these luminophore profiles. We used a non-local instead of the classical biodiffusion model, because the assumptions of the latter are not fulfilled in shortterm experiments (Meysman et al. 2008), especially when bioturbation rates are low. We used the Continuous Time Random Walk model (Meysman et al. 2008), with a Poisson stepping process and a Gaussian step-length distribution. A single value for the non-local biodiffusion coeffiecient as a measure for mixing intensity, $D_{b}^{N L}$ in $\mathrm{cm}^{2} \mathrm{yr}^{-1}$, is calculated from the fitted parameters $\sigma$ (characteristic step length) and $\tau$ (average waiting time) as:

$$
D_{b}^{N L}=\frac{\sigma^{2}}{2 \tau}
$$

It was not relevant to measure bioturbation activity of Lanice conchilega since this species resides in its semipermanent tube and does not rework the sediment column.

Estimation of faunal respiration. Biomasses were used to estimate macrofaunal respiration. Wet weights of Abra alba and Nephtys sp. were converted to ashfree dry weight (AFDW) using seasonally dependent conversion factors (Sistermans et al. 2004). AFDW of Lanice conchilega was estimated from mean tube diameter (Van Hoey 2006). For all species, $50 \%$ of this AFDW was considered to be carbon. Respiration rate was calculated by means of the Mahaut et al. (1995) formula for shallow water macrobenthos:

$$
R=0.0174 W^{0.844}
$$

where $R$ is respiration $\left(\mathrm{mg} \mathrm{C} \mathrm{d}^{-1}\right)$ and $W$ is mean individual AFDW (mg C), valid for the temperature range of 15 to $20^{\circ} \mathrm{C}$. Respiration was then corrected for temperature assuming a $Q_{10}$ of 2 and converted to oxygen consumption assuming a respiratory quotient of 0.85 . 
Mass budget calculation. The sediment-water exchange fluxes of $\mathrm{O}_{2}, \mathrm{NO}_{\mathrm{x}}$ and $\mathrm{NH}_{\mathrm{x}}$ were used to quantify denitrification, nitrification, total carbon and nitrogen mineralization. This was done by constructing an integrated mass budget of oxygen, nitrate and ammonium in the sediment as a function of the source and sink processes (Soetaert et al. 2001). Oxygen is either directly consumed to oxidise organic carbon (oxic mineralization [OxicMin]), or indirectly through the re-oxidation of reduced substances formed by anoxic mineralization (AnoxicMin). To re-oxidise all reduced substances formed upon anoxic mineralization, one mole of oxygen is consumed for each mole of carbon originally mineralised. Part of the reduced substances can remain buried in the sediment (pSolidDepo) and is therefore not re-oxidised. It is assumed that the (molar) O:C ratio of organic matter equals 1 . In addition, 2 moles of oxygen are required to oxidise ammonium to nitrate (Nitrification). Ammonium is the product of the mineralisation of organic nitrogen (Nmineralisation), but it is consumed by nitrification. Nitrification produces nitrate, but Denitrification consumes it; 0.8 moles of $\mathrm{NO}_{3}$ are consumed for 1 mole of carbon denitrified. Oxygen, nitrate and ammonium are exchanged through the sediment-water interface $\left(\mathrm{O}_{2}\right.$ inFlux, $\mathrm{NO}_{x}$ inFlux, $\mathrm{NH}_{\mathrm{X}}$ inFlux $)$.

These mass balances are summarised below.

$$
\begin{aligned}
& \frac{\mathrm{dO}^{2}}{\mathrm{dt}}=\mathrm{O}_{2} \mathrm{inFlux}-\text { OxicMin - AnoxicMin } \times \\
& (1-\text { pSolidDepo })-\text { Nitrification } \times 2 \\
& \frac{\mathrm{dNH}_{x}}{\mathrm{dt}}=\mathrm{NH}_{x} \text { inFlux }+ \text { Nmineralisation - } \\
& \begin{aligned}
\frac{\mathrm{dNO}_{x}}{\mathrm{dt}}= & \mathrm{NH}_{\mathrm{X}} \text { inFlux }+ \text { Nitrification }- \\
& \text { Denitrification } \times 0.8
\end{aligned}
\end{aligned}
$$

The exchanges across the sediment-water interface $\left(\mathrm{O}_{2}\right.$ inFlux, $\mathrm{NH}_{x}$ inFlux, $\mathrm{NO}_{x}$ inFlux $)$ were estimated during the incubation experiments, while the rate of change of oxygen $\left(\mathrm{dO}^{2} / \mathrm{dt}\right)$, nitrate $\left(\mathrm{dNO}_{X} / \mathrm{dt}\right)$ and ammonium $\left(\mathrm{dNH}_{x} / \mathrm{dt}\right)$ fluxes was assumed to be zero (geochemical steady state reached $1 \mathrm{wk}$ after introducing organisms). With 5 remaining unknowns (OxicMin, AnoxicMin, Nmineralization, Nitrification, Denitrification) and only 3 equations, the mass balance model has no unique solution.Therefore, we make the assumption that the burial of anoxic substances can be ignored $(\mathrm{pSolidDepo}=0)$. This allows combining the oxic and anoxic mineralization into one quantity (oxicAnoxicMin). The extra equation to balance the model then imposes a relationship between nitrogen and carbon mineralization, using the average N_C ratio as measured in the sediment. This ratio equalled 0.1959 (mol $\mathrm{N}$ mol $\mathrm{C}^{-1}$ ). The mass balances then become:

$$
\begin{aligned}
& 0=\mathrm{O}_{2} \text { inFlux }- \text { OxicAnoxicMin }- \text { Nitrification } \times 2 \\
& 0=\mathrm{NH}_{X} \text { inFlux }+ \text { Nmineralisation }- \text { Nitrification } \\
& 0=\mathrm{NO}_{X} \text { inFlux }+ \text { Nitrification }- \text { Denitrification } \times 0.8 \\
& \text { where, }
\end{aligned}
$$$$
\text { Nmineralisation }=(\text { OxicAnoxicMin }+ \text { Denitrification }) \times
$$$$
\mathrm{N} \text { :C ratio }
$$

These 3 equations can be solved for the 2 unmeasured quantities (OxicAnoxicMin, Nitrification) using least squares techniques. However, when measured denitrification rates were introduced in the mass budget, the model did not fit well with the other introduced quantities. As the measurement of denitrification was considered to be the least accurate, we chose to run the mass budget considering denitrification as an extra unknown to be fitted, i.e. imposing only $\mathrm{O}_{2}$ inFlux, $\mathrm{NH}_{\mathrm{x}}$ inFlux and $\mathrm{NO}_{\mathrm{x}}$ inFlux as input. With 3 equations and 3 unknowns this makes the model evenly determined. The modelled denitrification can then be compared with our measured rates a posteriori. The mass balance modelling was done using package limSolve (Soetaert et al. 2008) available in the open source software R (R Development Core Team 2009).

We chose to make measurements of several aspects of the $\mathrm{N}$ cycle rather than analyse a large number of replicates of fewer variables using a variance based statistical approach. The latter strategy allows for detection of significant differences in the measured variables (Benedetti-Cecchi 2004), but we aimed to obtain a more holistic view by performing measurements of different $\mathrm{N}$-cycle related processes covarying with ammonium fluxes (nitrate fluxes, oxygen fluxes, $\mathrm{N}_{2}$ fluxes) in combination with modelling of individual flux terms subjected to overall mass balance constraints. This allowed us to (1) assess the robustness of single measurements and (2) understand why patterns were observed.

Statistical analyses. Student's $t$-tests were performed with Statistica 6.0 software to test for differences in pigment concentrations between winter and summer. Homogeneity of variances was verified with a Levene's test. Data were log transformed when the assumptions were not met. Relations between densities and measured fluxes, stimulation of sediment community oxygen consumption (SCOC), $D_{b}^{N L}$ and $D_{b}^{N L}$ standardised for biomass were tested with linear regression analysis. Assumptions for the use of linear regressions were verified graphically. Normality of residuals was confirmed numerically with a ShapiroWilks test. When the assumption of linearity was not observed and it was biologically relevant to do so, a lack of fit test was performed to check whether a quadratic function described the data better than a linear one. Additional analyses of covariance (ANCOVA) 
were conducted to compare slopes of regressions. The level for statistical significance was set at 0.05 and only significant relations are shown in tables. Results are shown as means $\pm \mathrm{SE}$.

\section{RESULTS}

\section{In situ sediment characteristics}

Chl a concentrations in the water column were low in February (winter) $\left(1.05 \pm 0.04 \mu \mathrm{g} \mathrm{l}^{-1}\right.$ and $1.36 \pm$ $0.23 \mu \mathrm{g}^{-1}$ in surface and bottom water, respectively). This applies to the sediment as well: in the top $5 \mathrm{~cm}$ $26.99 \pm 4.77 \mathrm{mg} \mathrm{chl} \mathrm{a} \mathrm{\textrm {m } ^ { - 2 }}$ was found in February. In late August (summer), water chl a concentrations were higher $\left(7.28 \pm 0.87 \mu \mathrm{g} \mathrm{l}^{-1}\right.$ and $3.96 \pm 1.04 \mu \mathrm{g} \mathrm{l}^{-1}$ in surface and bottom water respectively) (Student's $t$-test, $t=-12.76, \mathrm{p}=0.0002$ and $t=-3.66, \mathrm{p}=0.02$, respectively). Sediment concentrations were $33.71 \pm 4.6 \mathrm{mg}$ chl a $\mathrm{m}^{-2}$ in the top $5 \mathrm{~cm}$ sediment and, thus, comparable with winter values) (Student's $t$-test, $\mathrm{p}=0.22$ ).

\section{Bioturbation}

The surface of control cores was smooth, with a brown-gray zone reaching $0.5 \mathrm{~cm}$ into the sediment. Below this oxic-suboxic zone, the sediment was black. In both winter and summer, all surfaces of Abra alba treatments were bumpy, with a grayish zone extending to $2 \mathrm{~cm}$ depth. Actual and deserted feeding pits (Maire et al. 2007) were visible along the core walls. The depth of the grayish zone in Lanice conchilega cores did not differ from control cores. During the whole experiment $L$. conchilega was very active, which was evident by the length (up to $10 \mathrm{~cm}$ ) of the reconstructed tubes above the sediment surface and the number of newly built fringe rims. Much surficial sand had been replaced for the construction of these fringes. Where polychaetes had constructed their U-shaped tubes with one leg of the $U$ against the core wall, a grayish zone of $5 \mathrm{~mm}$ was visible along the tubes reaching down to $10 \mathrm{~cm}$ depth. The grayish zone in Nephtys sp. cores was similarly shallow, but the remains of burrows, which were very narrow conical structures, were abundant along the core wall.

At the end of the winter experiment, Abra alba specimens were recovered in the first $5 \mathrm{~cm}$ of the sediment while the individuals remained in the upper $2.5 \mathrm{~cm}$ in summer. Nephtys sp. were found at 3.5 and $4 \mathrm{~cm}$ depths in winter and summer, respectively.

The bioturbation rate $D_{b}^{N L}$ in control cores was very low $\left(0.22 \pm 0.05 \mathrm{~cm}^{2} \mathrm{yr}^{-1}\right)$, indicating that the observed luminophore displacements in animal cores resulted from bioturbation. In all treatments, deep tracers were recovered at the depth of introduction, indicating that particle mixing was restricted to the top few centimetres. In winter, $2 \%$ of the luminophores administered to the surface were recovered below $0.5 \mathrm{~cm}$ in control cores, 15 to $37 \%$ were recovered in Abra alba sediments (from lowest to natural density) and 4 to $22 \%$ (both replicates of low density) were recovered in Nephtys sp. sediments. In summer, 1 to $5 \%$ luminophores were recovered below $0.5 \mathrm{~cm}$ in control cores, 13 to $42 \%$ were recovered in $A$. alba (from lowest to natural density) cores and 5 to $10 \%$ were recovered in Nephtys sp. cores (from natural to low density).

Bioturbation activity increased significantly (Fig. 2, Table 2) with Abra alba density in winter and not significantly (but nearly so) in summer ( $p=0.051$ ) $\left(D_{b}^{N L}\right.$ range from 0.96 to $\left.4.47 \mathrm{~cm}^{2} \mathrm{yr}^{-1}\right)$ but not with density of Nephtys sp. ( $D_{b}^{N L}$ range from 0.29 to $1.22 \mathrm{~cm}^{2}$ $\left.\mathrm{yr}^{-1}\right)$. Bioturbation rate of $A$. alba, standardised for grams (g) AFDW, showed no significant density dependence, implying that individual $D_{b}^{N L}$ was identical among density treatments. Nephtys sp. bioturbation rate standardised for biomass tended to diminish with increasing densities in both winter and summer, but not significantly, however.

\section{Oxygen penetration depth and consumption}

In summer, oxygen was generally depleted at $3 \mathrm{~mm}$ depth, except in the Lanice conchilega cores (Fig. 3). While oxygen penetration in between tubes (4.4 \pm $0.3 \mathrm{~mm}$ ) was similar to observations in control cores $(3.2 \pm 0.2 \mathrm{~mm})$, there was a deeper penetration near the tubes $(6.3 \pm 1.6 \mathrm{~mm})$. This oxygen penetration depth tended to increase with $L$. conchilega densities, but this relation was not significant.

Control SCOC in the summer experiment was 2.0 times higher than in the winter experiment. In winter, SCOC increased significantly with densities of Abra alba and Lanice conchilega (Table 2), but not with Nephtys sp. densities. SCOC depended more on L. conchilega densities than on A. alba densities (ANCOVA, $\mathrm{p}<0.05)$. Summer SCOC was significantly related only to L. conchilega densities, but more strongly than in winter (ANCOVA, p < 0.001). Linear regression analysis in function of biomass yielded very similar results as the results in function of density (Table 3, Fig. 4).

\section{Nutrient fluxes}

Ambient water $\mathrm{NO}_{x}$ and $\mathrm{NH}_{x}$ concentrations averaged, respectively, 3 and $3.5 \mu \mathrm{M}$ in winter and 1 and $2.5 \mu \mathrm{M}$ in summer. Only effluxes of nutrients were 
observed, except for one low density replicate of Nephtys sp. $\mathrm{NH}_{x}$ effluxes were highest in Lanice conchilega treatments (overall average: $4.17 \pm 0.56 \mathrm{mmol}$ $\left.\mathrm{N}-\mathrm{NH}_{\mathrm{X}} \mathrm{m}^{-2} \mathrm{~d}^{-1}\right)$. L. conchilega winter effluxes were very variable and no density pattern was detected. In summer, $\mathrm{NH}_{x}$ effluxes tended to increase with this polychaete's densities $(p=0.07) . \mathrm{NH}_{\mathrm{x}}$ effluxes increased significantly with Abra alba densities
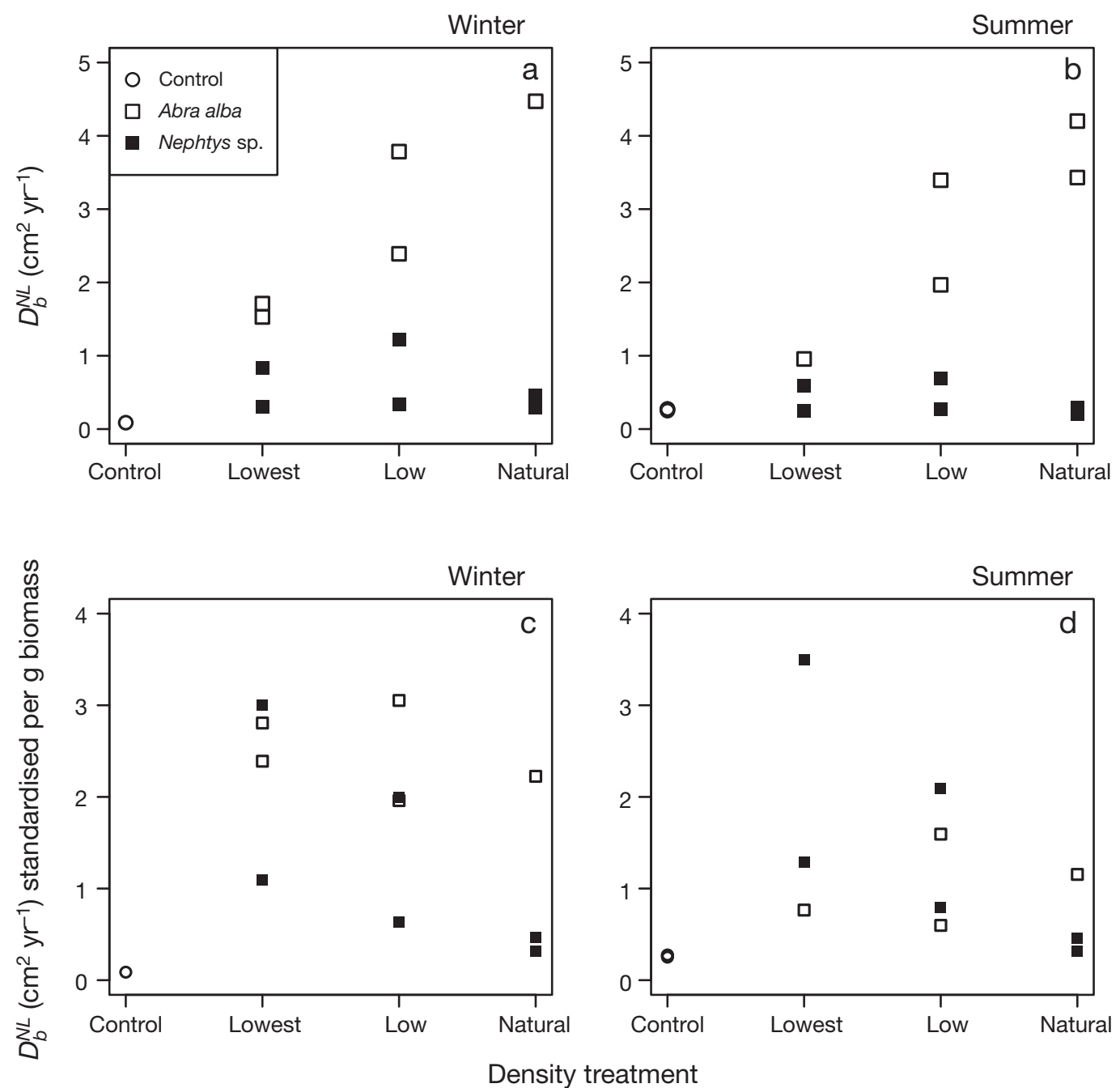

Fig. 2. Abra alba and Nephtys sp. Bioturbation rate $D_{b}^{N L}$ (as $\mathrm{cm}^{2}$ of sediment reworked per year) per density level for each species for (a) winter and (b) summer and standardized for biomass (grams AFDW) of added fauna for (c) winter and (d) summer

Table 2. Abra alba, Lanice conchilega and Nephtys sp. Significant simple linear regressions of ecosystem functions on species densities. $\mathrm{n}=9$, except for $A$. alba bioturbation $(\mathrm{n}=5)$. SCOC: Sediment community oxygen consumption

\begin{tabular}{|c|c|c|c|c|c|c|}
\hline \multirow[t]{2}{*}{ Species } & \multirow{2}{*}{ Time } & \multirow{2}{*}{ Ecosystem function } & \multicolumn{4}{|c|}{ - Linear regression analyses } \\
\hline & & & a & $b$ & $\mathrm{R}^{2}$ & $\mathrm{p}$ (slope) \\
\hline \multirow[t]{5}{*}{ A. alba } & \multirow[t]{4}{*}{ Winter } & Bioturbation & $1.27 \mathrm{E}-3$ & 8.89E-6 & 0.79 & 0.028 \\
\hline & & $\mathrm{NH}_{X}$ release & 0.19 & 0.001 & 0.42 & 0.030 \\
\hline & & $\mathrm{SCOC}$ & 13.37 & 0.005 & 0.74 & 0.002 \\
\hline & & Denitrification & 0.08 & 0.001 & 0.90 & $<0.001$ \\
\hline & Summer & $\mathrm{NH}_{X}$ release & 2.18 & 0.002 & 0.58 & 0.001 \\
\hline \multirow[t]{3}{*}{ L. conchilega } & Winter & $\mathrm{SCOC}$ & 15.16 & 0.011 & 0.50 & 0.019 \\
\hline & Summer & $\mathrm{SCOC}$ & 30.27 & 0.042 & 0.78 & $<0.001$ \\
\hline & & Denitrification & \multicolumn{4}{|c|}{ Quadratic function, see Fig. 5 for formula } \\
\hline Nephtys sp. & Winter & Denitrification & 0.12 & 0.002 & 0.78 & $<0.001$ \\
\hline
\end{tabular}




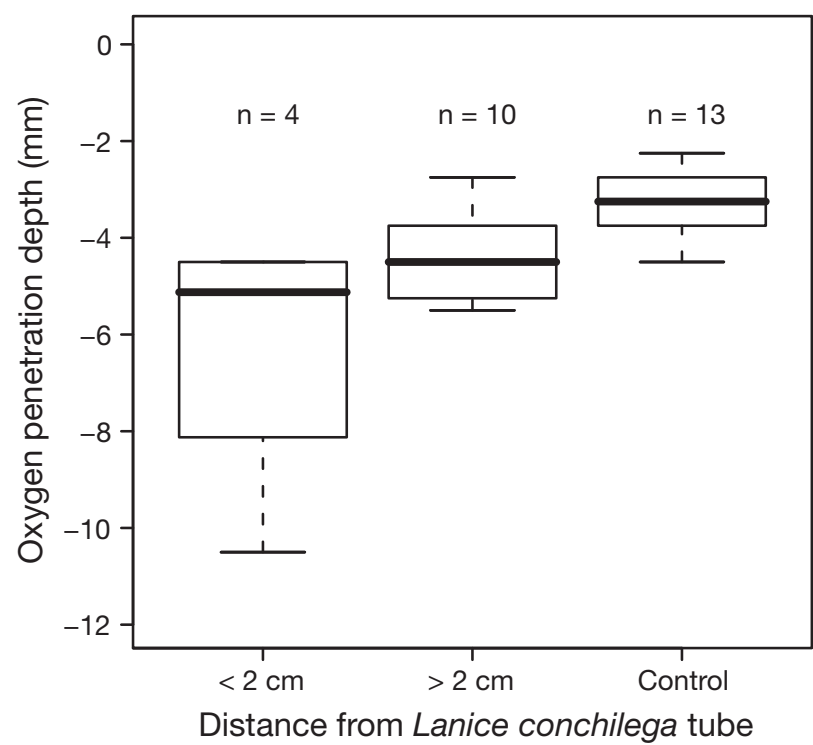

Fig. 3. Lanice conchilega. Boxplot indicating the influence of distance from tube on oxygen penetration compared with control: Thick black lines show the median. Box is drawn between the quartiles. Dotted lines extend to the minimum and maximum values

(Table 2) both during winter and summer. There was no linear relationship between $\mathrm{NO}_{x}$ effluxes and either densities or species.

\section{Nitrogen cycling}

The mass balance approach yielded good fits to measured oxygen consumption rates and ammonium and nitrate effluxes. Modeled and MIMS based denitrification rates agreed fairly well, except for the Lanice conchilega treatments in winter, where measured denitrification was significantly higher than that for modeled denitrification. This difference can be explained either by logistical problems with MIMS measurements or by the lack of steady state conditions. Because of this, we did not test density dependence of denitrification in these L. conchilega winter treatments. In winter, measured denitrification increased significantly with densities of Abra alba and Nephtys sp. (Table 2). In

Table 3. Abra alba and Lanice conchilega. Significant simple linear regression of sediment community oxygen consumption (SCOC) as a function of species ash free dry weight

\begin{tabular}{|lccccc|}
\hline Species & Time & \multicolumn{4}{c|}{ Linear regression analyses } \\
& & $a$ & $b$ & $\mathrm{R}^{2}$ & $\mathrm{p}$ \\
& & & & & (slope) \\
\hline A. alba & Winter & 13.37 & 0.055 & 0.74 & 0.002 \\
L. conchilega & Winter & 15.15 & 0.106 & 0.51 & 0.019 \\
& Summer & 29.42 & 0.220 & 0.83 & $<0.001$ \\
\hline
\end{tabular}

summer, a quadratic function described the pattern of denitrification versus $L$. conchilega densities better than a linear function (Fig. 5), and denitrification was maximal at 'low' density.

Nitrification was calculated from the balance of measured $\mathrm{O}_{2}, \mathrm{NO}_{x}$ and $\mathrm{NH}_{x}$ effluxes and modeled denitrification. In winter, none of the treatments had higher nitrification rates than control cores (not depicted, but see Fig. 7). In summer, the low and natural Lanice conchilega density treatments and lowest and natural Nephtys sp. density yielded higher nitrification rates than did controls. Abra alba did not exhibit any influence on nitrification rates.

Nitrogen mineralization is the balance of $\mathrm{NO}_{x}, \mathrm{NH}_{x}$ and $\mathrm{N}_{2}$ effluxes and is proportional to SCOC, apart from denitrification, which contributes a relatively small part to the total mineralization (averaged over all treatments: $8.9 \pm 1.0 \%$ ). SCOC can be attributed to background microbial oxygen consumption, macrofaunal respiration and macrofauna-mediated microbial consumption (Glud 2008, Na et al. 2008). The contribution of the latter can roughly be estimated as the difference between measured SCOC and the sum of background (averaged control) SCOC measurements and estimated macrofaunal respiration derived from biomass data. Positive numbers indicate a macrofaunamediated enhanced microbial activity (Marinelli \& Boudreau 1996, Na et al. 2008).

Species treatments enhanced benthic mineralization differently in winter and summer. In winter, positive numbers were noted in low and natural Abra alba and Lanice conchilega densities (Fig. 6). In contrast, negative numbers were observed in lowest $A$. alba densities and all Nephtys sp. treatments. As these negative values are biologically unlikely, they could indicate estimation errors on faunal respiration. This implies that the positive deviations are too small to conclude that microbial respiration is enhanced convincingly by $A$. alba and L. conchilega in winter. In contrast, excess L. conchilega respiration in summer was obviously sufficiently large to classify as fauna-mediated microbial respiration. Fauna-mediated microbial respiration increased significantly with $L$. conchilega densities $\left(\mathrm{R}^{2}=0.77, \mathrm{p}=0.01\right)$ even up to $100 \%$ higher than in the control at one natural density. A. alba and Nephtys sp. did not seem to mediate microbial respiration in summer.

\section{DISCUSSION}

The use of laboratory controlled microcosms containing defaunated sediment with artificially composed fauna communities is a suitable approach to detect the effects of a single species on biogeochemical cycling. Extrapolating the results of these microcosm experi- 


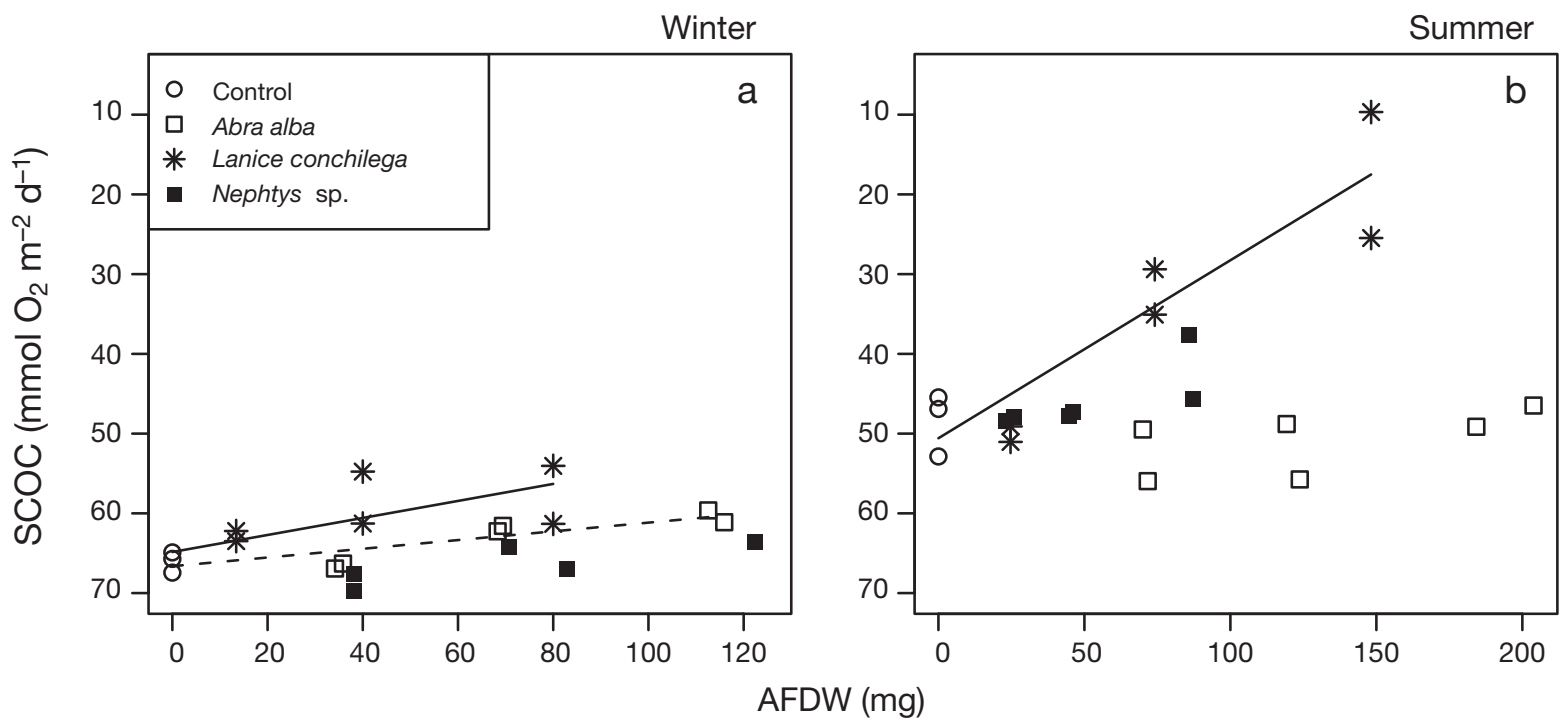

Fig. 4. Abra alba, Lanice conchilega and Neptys sp. Sediment community oxygen consumption (SCOC) as $\mathrm{mmol}_{2} \mathrm{~m}^{-2} \mathrm{~d}^{-1} \mathrm{per}$ species as a function of their ash free dry weight (AFDW) for (a) winter (b) summer. Significant regressions of SCOC on A. alba densities (solid line) and $L$. conchilega (dashed line) are indicated. Note the $x$-axis scales are different

ments to broad-scale ecosystem functioning, however, should be done with caution, since the microcosm is a highly simplified and tightly controlled artificial system. Under natural conditions, the role of each of the isolated species in this study will rather be a function of the complex interactions of competition for space and food (Ieno et al. 2006), macrofauna patchiness (Barry \& Dayton 1991, McIntosh 1991), sediment dynamics and water flow (Biles et al. 2003, Tengberg et al. 2003 and references therein).

Nevertheless, microcosm experiments provide a mechanistic understanding of ecological processes, thereby supplying mathematical models with the necessary biological information for parameter selection and estimation and influencing the development of theories that are of fundamental importance to address global ecological issues (Benton et al. 2007). Therefore, they are a natural step between mathematical modeling and necessary empirical tests in large-scale marine systems (Oksanen 2001).

Benthic activity in the North Sea is influenced by the seasonal input of organic matter (Boon \& Duineveld 1998), but because benthic chl a concentrations in our experiments were similar in summer and winter, the fresh, highly labile organic matter was probably already mineralized (van Oevelen et al. 2009). Nevertheless, higher sediment-water exchange fluxes were observed in the microcosms in summer, in large part due to macrofaunal stimulation. The higher macrobenthic activity in summer can thus be explained by the higher temperature and better condition of the animals, i.e. they were better fed at the time of field sampling.

\section{MECHANISTIC EXPLANATION OF THE RELATIONSHIP BETWEEN FUNCTIONAL TRAITS AND ECOSYSTEM FUNCTIONING}

Benthic mineralization makes nutrients available to the pelagic algae (Soetaert et al. 2001). Deposited particulate OM is first mineralized to carbon dioxide and ammonium (Fig. 7). In the presence of oxygen, ammonium can subsequently be oxidized to nitrite and nitrate, which serve as substrates for denitrification under anoxic conditions. The nitrogen gas resulting from

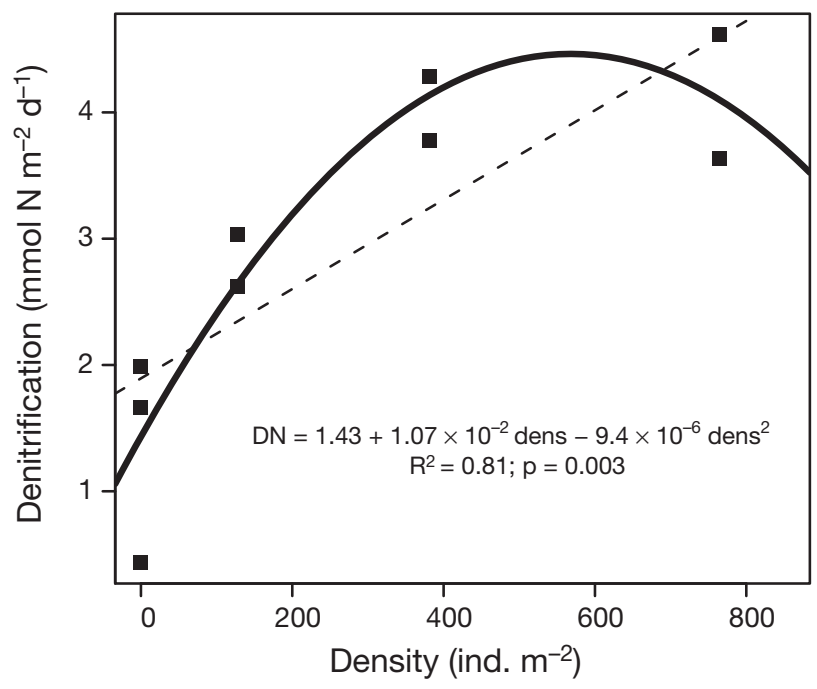

Fig. 5. Lanice conchilega. Denitrification as a function of densities in summer. Lack of fit test indicated a better fit by quadratic rather than linear function 

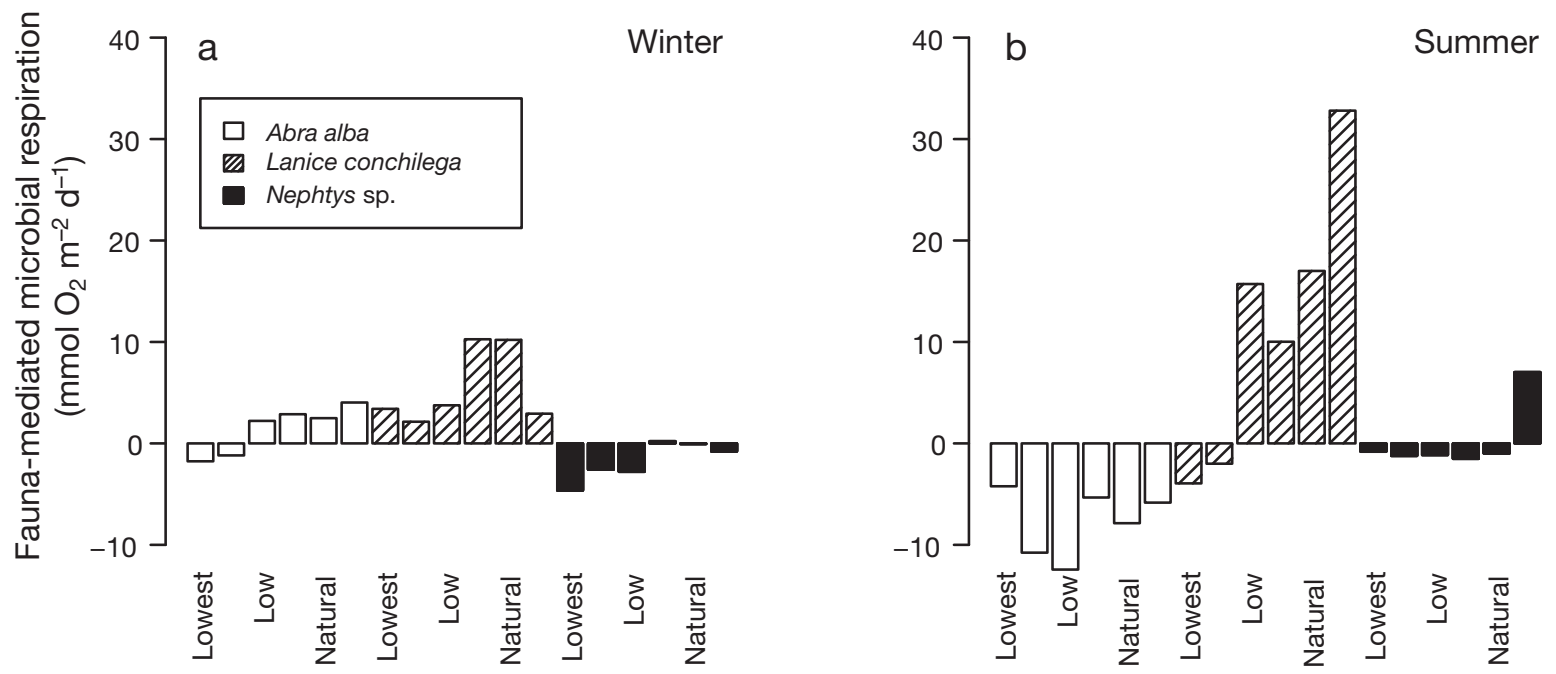

Density treatment

Fig. 6. Abra alba, Lanice conchilega and Nephtys sp. Fauna-mediated microbial respiration (for (a) winter and (b) summer) for increasing densities of all species in $\mathrm{mmol} \mathrm{O}_{2} \mathrm{~m}^{-2} \mathrm{~d}^{-1}$. Values are calculated as measured sediment community oxygen consumption (SCOC) minus predicted SCOC

this process is not available to most micro-organisms and eventually escapes to the air. This transfer of fixed nitrogen to nitrogen gas is important in coastal systems, because it counteracts $\mathrm{N}$ eutrophication.

In the absence of fauna (control cores), SCOC was 2.0 times higher in summer compared with winter (Fig. 7a), which can be primarily attributed to a temperature effect $\left(Q_{10}=2.4\right)$, since sediment chl a concentrations were similar. The higher mineralisation in the summer experiment (reflected in SCOC) resulted in more ammonium production, higher $\mathrm{NH}_{\mathrm{x}}$ effluxes and higher nitrification rates. The resulting nitrate was partly lost to the water column as the nutrient concentrations in the overlying water were low. Nevertheless, sufficient nitrate was available in the sediment to fuel denitrification.

Bio-irrigation and bioturbation influenced these processes and the stimulation by the 3 studied species was different, which can be explained by their behaviour. Abra alba resides in the upper 3 to $4 \mathrm{~cm}$ of the sediment (Degraer et al. 2006), extending its siphons to the sediment surface. The oxygenated water transported through the siphons is not in direct contact with the surrounding sediment, but the siphonal channels of Abra spp. are probably important in bringing oxygen to deeper strata (Wikander 1980). Although the sediment was thoroughly reworked in both experiments and the gray color indicated reoxidation of reduced metabolites, the oxygenated layer was not extended compared with the control (Fig. 7b). This is reflected in the observed fluxes: oxygen consumption at natural A. alba density was comparable with controls in both winter and summer experiments, while ammonium effluxes were enhanced by a factor 3.3 in summer, at the expense of nitrification and denitrification.

Similarly, Davis \& Miller (1979) expected an enhanced oxygenation through burrow walls of Nephtys sp. The sediment surrounding burrow linings was indeed gray, but overall oxygen penetration depth in Nephtys sp. cores did not differ from the control depth. SCOC was 2.0 times higher in summer compared with winter, while ammonium effluxes were 3.2 times higher (Fig. 7d). Given that only $20 \%$ of the ammonium efflux can be attributed to animal excretion (Christensen et al. 2000), the greater ammonium effluxes in the cores must have been supported by enhanced ammonium regeneration, at the same time fuelling nitrification and indirectly denitrification. Our observations of Nephtys sp. barely bioturbating and enhancing sediment-water fluxes deviate somewhat from expectations based on Nephtys life history in natural conditions. Nephtys sp. is an active predator (e.g. Fauchald \& Jumars 1979), able to cope with high environmental stress (Arndt \& Schiedek 1997). Food supply greatly increases bioturbation and ventilation by the polychaete Nereis diversicolor (Kristensen 1989, Nogaro et al. 2008). When no food is found, $N$. diversicolor returns to its burrow and resumes ventilation activity. As no extra food was added to the experimental cores, we suggest that the defaunated sediment deprived these predators of suitable prey and made them adopt an energy saving behaviour, especially in winter.

In contrast to Abra alba and Nephtys sp., Lanice conchilega generated the highest fluxes, in winter and 
summer (Fig. 7c). This might be explained by the fact that A. alba and Nephtys sp. do not actively irrigate their burrows/feeding pits; hence, their influence on measured fluxes is limited. Similarly, MermillodBlondin et al. (2004) and Michaud et al. (2005, 2006) observed fairly small effects of natural densities of the bivalves Cerastoderma edule and Macoma balthica, also biodiffusers, on sediment-water fluxes.

Oxygen penetration depth in Lanice conchilega microcosms was larger than those for the other species and control treatments. Varying penetration depths were observed, depending on the distance to the polychaete tube. Even though $L$. conchilega feeds via suspension-deposit feeding and respires using gills at its anterior end, the species ventilates its tube for $1.5 \mathrm{~min}$ every $4 \mathrm{~min}$, transporting about $8 \mu \mathrm{mol} \mathrm{O}_{2}$ ind. $^{-1}$ $\mathrm{d}^{-1}$ into the sediment (Forster \& Graf 1995), leading to an oxic layer surrounding the tubes and with oxygen concentration reaching $20 \%$ of air saturation up to the $55 \mathrm{~mm}$ depth. This larger oxic volume might stimulate microbial mineralization and generation of ammonium. Combined with the strong pumping behaviour of this species, this clarifies the very high ammonium effluxes in treatments of $L$. conchilega. According to the mass balance estimates, these ammonium effluxes were too large to sustain nitrification and denitrification as high as observed in the control microcosms in winter. Moreover, modelled denitrification rates were far below rates measured by MIMS. Although MIMS-based denitrification has its limitations (see 'Materials and methods'), we believe that the discrepancy can be attributed to a lack of steady state conditions and thus the applicability of the mass balance approach adopted. Introducing bio-irrigators to a defaunated sediment column will delay reaching a steady state situation (Banta et al. 1999), which is typically characterised by very high ammonium effluxes due to the high amount of labile OM that becomes available ( $\mathrm{Na}$ et al. 2008). However, ammonium effluxes and oxygen influxes were better balanced in the summer experiment. Intermittent ventilation patterns may promote variable $\mathrm{O}_{2}$ conditions in and around the tubes (Kristensen 1988) with repercussions on other fluxes. The ammonium that accumulated in and around the L. conchilega tubes was presumably
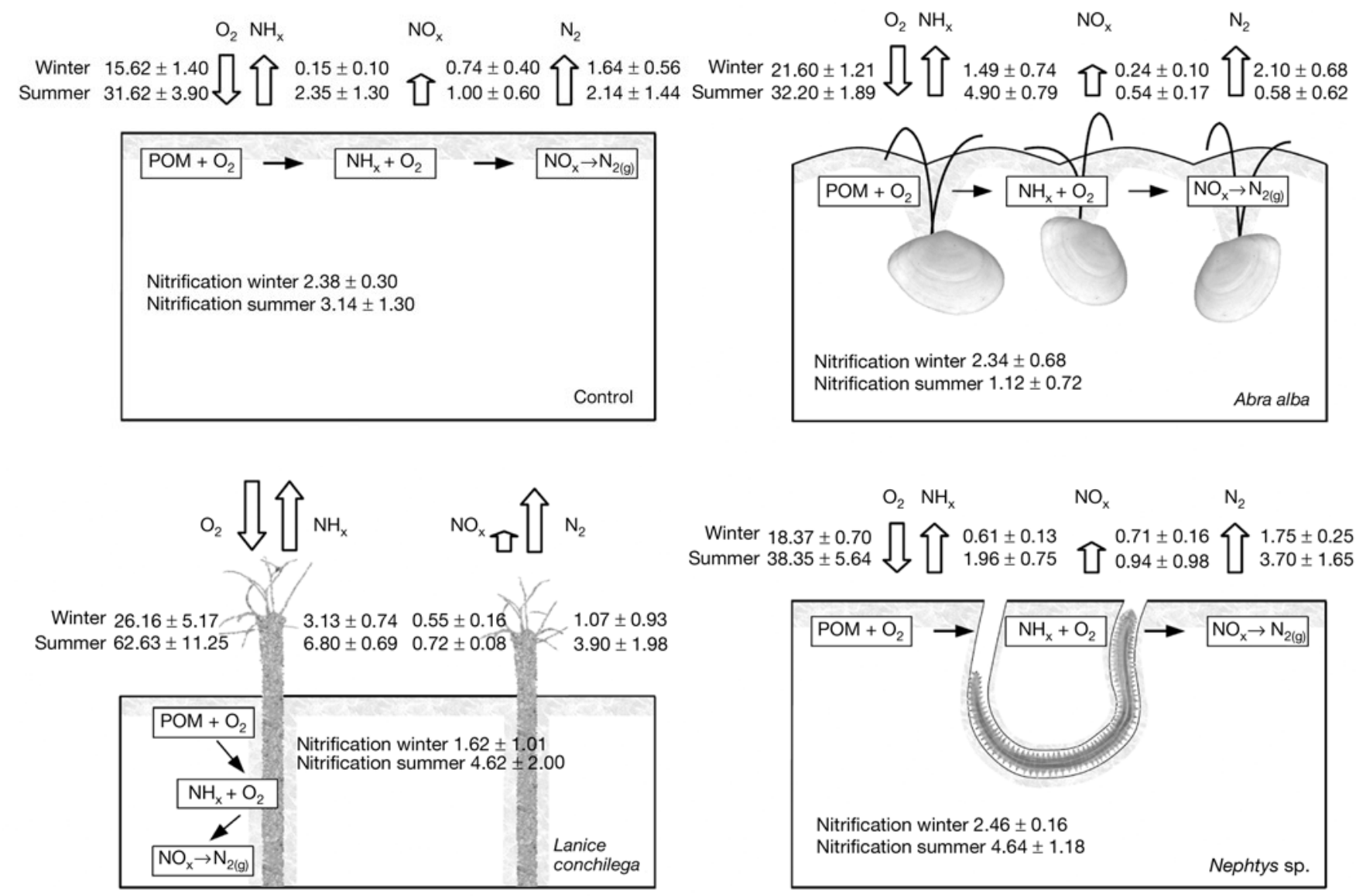

Fig.7. Abra alba, Lanice conchilega and Nephtys sp. Schemes of mass balanced processes at natural density for each species

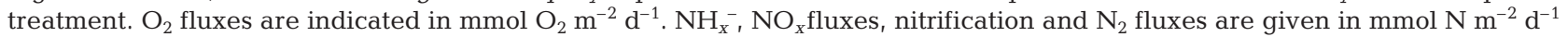
(multiply by 0.8 to express in mmol Cor $\mathrm{O}_{2} \mathrm{~m}^{-2} \mathrm{~d}^{-1}$ ) 
nitrified to nitrate during a resting period of the polychaete until oxygen was depleted, and nitrate denitrified to $\mathrm{N}_{2}$. In the next irrigation period, this $\mathrm{N}_{2}$ gas and remaining ammonium were flushed out and fresh oxygenated water drawn into the sediment. In cores with a natural density of $L$. conchilega, benthic mineralization in summer was doubled compared with the control. This is of the same order of what has been found by Kristensen \& Blackburn (1987) for Nereis virens and by Banta et al. (1999) for Arenicola marina and confirms that bio-irrigation influences mineralization and $\mathrm{N}$ cycling more drastically than bioturbation (Mermillod-Blondin et al. 2004).

\section{Importance of density}

For many ecosystem processes there were no significant density effects, but there were some notable exceptions. In these cases decreases in densities may have implications for ecosystem functioning.

Bioturbation rate and ammonium effluxes increased in both experiments with density of Abra alba. The intense bioturbation and thus downward transport of $\mathrm{OM}$ is important for the food such as bacteria and meiobenthos (Levin et al. 1997, Witte et al. 2003) and microbial decomposition and mineralization processes that consume oxygen and release $\mathrm{NH}_{\mathrm{x}}$ (Herman et al. 1999, Thrush et al. 2006). The standardized $D_{b}^{N L}$ of $A$. alba was higher in winter than in summer. Considering the lower biomasses in winter, this can indicate a higher bioturbation activity of the invertebrates in winter. Another possibility is that A. alba body mass does not significantly affect the individual's bioturbation activity, which mainly results from siphon movements.

Nephtys sp. populations did not rework the sediment actively, but when standardised to biomass, the bioturbation rate dropped with increasing densities. This has also been observed for Nereis diversicolor (Duport et al. 2006) and has been linked to territorial behaviour (Miron et al. 1992).

Oxygen penetration tended to increase with Lanice conchilega densities. We did not manipulate densities up to 5000 ind. $\mathrm{m}^{-2}$ as found in reefs (Rabaut et al. 2009) because of experimental restrictions. Nevertheless, at a certain tube density the oxygenated zones will overlap; thus, even small reefs of $L$. conchilega can enhance oxygen penetration on a relatively large scale. Interestingly, denitrification in $L$. conchilega treatments reached a maximum at 'low' density. Aller (1988) showed that denitrification potential initially increases with density and then drops at a certain tube density. This is explained by over-oxygenation causing large reduction of sediment areas for coupled nitrification/denitrification. However, this should be further explored with higher L. conchilega densities, as it may show a different pattern at reef dimensions.

Our approach involved natural and lower densities rather than artificially high densities, although use of the latter would facilitate observation of the effect. We believe that comparing the effects between natural populations of species has the advantage of estimating their relative importance in the field. As such, we can conclude that the natural density of Abra alba in the cores contributed more to sediment reworking than the natural Nephtys sp. density, which is related to a higher density and biomass. Finally, though at a lower natural density and biomass, adding Lanice conchilega to microcosms caused a more pronounced influence on fluxes than $\operatorname{did} A$. alba.

Acknowledgements. We thank the crew of RV 'Zeeleeuw', B. Beuselinck, J. Van Tomme, S. Degraer, K. Van Ginderdeuren and M. Rabaut for sampling assistance, the conservators of the Flemish Nature Reserve 'Baai van Heist' for entrance permission, J. Verstraete and H.E. Sinke for technical support and J. Peene and F. Gazeau for great help with MIMS. M. Rabaut and C. Van Colen are greatly acknowledged for fruitful discussions. Three anonymous referees are acknowledged for their critical suggestions. Support was given to U.B. by the Flemish Fund for Fundamental Research (FWO), to B.G. by the Netherlands Organisation of Scientific Research (NWO, VENI grant no. 863.05.005) and the Danish Agency for Science, Technology and Innovation (Steno grant no. 272-06-0253). This paper contributes to the Westbanks project (www.vliz.be/projects/westbanks), which is supported by the Belgian Science Policy (BEL$\mathrm{SPO}$; contract no. SD/BN/01A) to the Ghent University BBSea Project (GOA 01600705), FWO project (G.0041.08) and the EU Network of Excellence Marbef (GOCE-CT-2003-505446). This is NIOO-KNAW publication no. 4676 and Nereis Park publication no. 31. U.B and P.P. contributed equally to this study.

\section{LITERATURE CITED}

Aller RC (1988) Benthic fauna and biogeochemical processes in marine sediments: the role of burrow structures. In: Blackburn TH, Sørensen J (eds) Nitrogen cycling in coastal marine environments. Scope, Chichester, p 301-338

> Arndt C, Schiedek D (1997) Nephtys hombergii, a free-living predator in marine sediments: energy production under environmental stress. Mar Biol 129:643-650

Banta GT, Holmer M, Jensen MH, Kristensen E (1999) Effects of two polychaete worms, Nereis diversicolor and Arenicola marina, on aerobic and anaerobic decomposition in a sandy marine sediment. Aquat Microb Ecol 19:189-204

Barry JP, Dayton PK (1991) Physical heterogeneity and the organization of marine communities. In: Kolasa J, Pickett STA (eds) Ecological heterogeneity. Springer-Verlag. New York, p 270-320

Benedetti-Cecchi L (2004) Increasing accuracy of causal inference in experimental analyses of biodiversity. Funct Ecol 18:761-768

- Benton TG, Solan M, Travis JM, Sait SM (2007) Microcosm experiments can inform global ecological problems. Trends Ecol Evol 22:516-521

Bergman MJN, Hup M (1992) Direct effects of beam-trawling on macrofauna in a sandy sediment in the southern North Sea. ICES J Mar Sci 49:5-11 
Biles CL, Solan M, Isaksson I, Paterson DM, Emes C, Raffaelli DG (2003) Flow modifies the effect of biodiversity on ecosystem functioning: an in situ study of estuarine sediments. J Exp Mar Biol Ecol 285-286:165-177

Blackburn TH (1988) Benthic mineralization and bacterial production. In: Nitrogen cycling in coastal marine environments. In: Blackburn TH, Sørensen J (eds) Nitrogen cycling in coastal marine environments. Scope, Chichester, p 175-190.

Boon AR, Duineveld GCA (1998) Chlorophyll a as a marker for bioturbation and carbon flux in southern and central North Sea sediments. Mar Ecol Prog Ser 162:33-43

Callaway R (2006) Tube worms promote community change. Mar Ecol Prog Ser 308:49-60

Christensen B, Vedel A, Kristensen E (2000) Carbon and nitrogen fluxes in sediment inhabited by suspension-feeding (Nereis diversicolor) and non-suspension-feeding $(N$. virens) polychaetes. Mar Ecol Prog Ser 192:203-217

Coleman FC, Williams SL (2002) Overexploiting marine ecosystem engineers: potential consequences for biodiversity. Trends Ecol Evol 17:40-44

Davis WR, Miller DC (1979) Burrowing activities and sediment impact of Nephtys incisa. In: Jacoff FS (ed) Advances in marine environmental research. Proc Symp US EPA 600/9-79-035, Narragansett, RI, p 302-319

Degraer S, Wittoeck J, Appeltans W, Cooreman K and others (2006). The macrobenthos atlas of the Belgian part of the North Sea. Belgian Science Policy, Brussels

$>$ Duport E, Stora G, Tremblay P, Gilbert F (2006) Effects of population density on the sediment mixing induced by the gallery-diffusor Hediste (Nereis) diversicolor O.F. Muller, 1776. J Exp Mar Biol Ecol 336:33-41

Fauchald K, Jumars PA (1979) The diet of worms: a study of polychaete feeding guilds. Oceanogr Mar Biol Annu Rev 17:193-284

Forster S, Graf G (1995) Impact of irrigation on oxygen flux into the sediment: intermittent pumping by Callianassa subterranea and "piston-pumping" by Lanice conchilega. Mar Biol 123:335-346

Franco MA, De Mesel I, Demba Diallo M, Van der Gucht K and others (2007) Effect of phytoplankton bloom deposition on benthic bacterial communities in two contrasting sediments in the southern North Sea. Aquat Microb Ecol 48:241-254

Franco MA, Soetaert K, Costa MJ, Vincx M, Vanaverbeke J (2008) Uptake of phytodetritus by meiobenthos using C-13 labelled diatoms and Phaeocystis in two contrasting sediments from the North Sea. J Exp Mar Biol Ecol 362:1-8

Gerino M, Aller RC, Lee C, Cochran JK, Aller JY, Green MA, Hirschberg D (1998) Comparison of different tracers and methods used to quantify bioturbation during a spring bloom: 234-thorium, luminophores and chlorophyll a. Estuar Coast Shelf Sci 46:531-547

Gerino M, Stora G, Francois F, Gilbert F and others (2003) Macro-invertebrate functional groups in freshwater and marine sediments: a common mechanistic classification. Vie Milieu 53:221-232

Glud RN (2008) Oxygen dynamics of marine sediments. Mar Biol Res 4:243-289

Godet L, Toupoint N, Olivier F, Fournier J, Retiere C (2008) Considering the functional value of common marine species as a conservation stake: the case of sandmason worm Lanice conchilega (Pallas 1766) (Annelida, Polychaeta) beds. Ambio 37:347-355

Hartmann-Schröder G (1996) Annelida, Borstenwürmer, Polychaeta. Die Tiewelt Deutschland 58. Gustav Fischer, Jena
Herman PMJ, Middelburg JJ, Van de Koppel J, Heip CHR (1999) Ecology of estuarine macrobenthos. Adv Ecol Res 29:195-240

> Ieno EN, Solan M, Batty P, Pierce GJ (2006) How biodiversity affects ecosystem functioning: roles of infaunal species richness, identity and density in the marine benthos. Mar Ecol Prog Ser 311:263-271

Jones CG, Lawton JH, Shachak M (1994) Organisms as ecosystem engineers. Oikos 69:373-386

Kana T, Darkangelo C, Hunt M, Oldham J, Bennett G, Cornwell J (1994) Membrane inlet mass-spectrometer for rapid high-precision determination of $\mathrm{N}_{2}, \mathrm{O}_{2}$ and $\mathrm{Ar}$ in environmental water samples. Anal Chem 66:4166-4170

Kristensen E (1988) Benthic fauna and biogeochemical processes in marine sediments: microbial activities and fluxes. In: Blackburn TH, Sørensen J (eds) Nitrogen cycling in coastal marine environments. Scope, Chichester, p 275-299

Kristensen E (1989) Oxygen and carbon-dioxide exchange in the polychaete Nereis virens: influence of ventilation activity and starvation. Mar Biol 101:381-388

Kristensen E, Blackburn TH (1987) Fate of organic carbon and nitrogen in experimental marine sediment systems: influence of bioturbation and anoxia. J Mar Res 45:231-257

Kristensen E, Kostka JE (2005) Macrofaunal burrows and irrigation in marine sediment: microbiological and biogeochemical interactions. In: Kristensen E, Haese RR, Kostka JE (eds) Interactions between macro- and microorganisms in marine sediments. American Geosciences Union Coastal and Estuarine Studies, Washington, DC, p 125-157

Levin L, Blair N, DeMaster D, Plaia G, Fornes W, Martin C, Thomas C (1997) Rapid subduction of organic matter by maldanid polychaetes on the North Carolina slope. J Mar Res 55:595-611

Mahaut M, Sibuet M, Shirayama Y (1995) Weight-dependent respiration rates in deep-sea organisms. Deep-Sea Res I 42:1575-1582

Maire O, Duchene JC, Gremare A, Malyuga VS, Meysman FJR (2007) A comparison of sediment reworking rates by the surface deposit-feeding bivalve Abra ovata during summertime and wintertime, with a comparison between two models of sediment reworking. J Exp Mar Biol Ecol 343:21-36

Marinelli RL, Boudreau BP (1996) An experimental and modeling study of $\mathrm{pH}$ and related solutes in an irrigated anoxic coastal sediment. J Mar Res 54:939-966

Marinelli RL, Williams TJ (2003) Evidence for densitydependent effects of infauna on sediment biogeochemistry and benthic-pelagic coupling in nearshore systems. Estuar Coast Shelf Sci 57:179-192

McIntosh RP (1991) Concept and terminology of homogeneity and heterogeneity in ecology. In: Kolasa J, Pickett STA (eds) Ecological heterogeneity. Springer-Verlag, New York, p 24-46

Mermillod-Blondin F, Rosenberg R, Francois-Carcaillet F, Norling K, Mauclaire L (2004) Influence of bioturbation by three benthic infaunal species on microbial communities and biogeochemical processes in marine sediment. Aquat Microb Ecol 36:271-284

> Meysman FJ, Middelburg JJ, Heip CH (2006) Bioturbation: a fresh look at Darwin's last idea. Trends Ecol Evol 21: 688-695

Meysman FJR, Malyuga VS, Boudreau BP, Middelburg JJ (2008) Quantifying particle dispersal in aquatic sediments at short time scales: model selection. Aquat Biol 2:239-254

Michaud E, Desrosiers G, Mermillod-Blondin F, Sundby B, Stora G (2005) The functional group approach to bioturbation: the effects of biodiffusers and gallery-diffusers of the 
Macoma balthica community on sediment oxygen uptake. J Exp Mar Biol Ecol 326:77-88

Michaud E, Desrosiers G, Mermillod-Blondin F, Sundby B, Stora G (2006) The functional group approach to bioturbation: II. The effects of the Macoma balthica community on fluxes of nutrients and dissolved organic carbon across the sediment-water interface. J Exp Mar Biol Ecol 337: 178-189

Miron G, Desrosiers G, Retière C (1992) Organization of fighting in the polychaete Nereis virens (Sars) and the effects of residency and orientation. Behaviour 121:20-34

Na T, Gribsholt B, Galaktionov OS, Lee T, Meysman FJR (2008) Influence of advective bio-irrigation on carbon and nitrogen cycling in sandy sediments. J Mar Res 66: 691-722

- Nogaro G, Charles F, Mendonca JD, Mermillod-Blondin F, Stora G, Francois-Carcaillet F (2008) Food supply impacts sediment reworking by Nereis diversicolor. Hydrobiologia 598:403-408

Norling K, Rosenberg R, Hulth S, Gremare A, Bonsdorff E (2007) Importance of functional biodiversity and speciesspecific traits of benthic fauna for ecosystem functions in marine sediment. Mar Ecol Prog Ser 332:11-23

Oksanen L (2001) Logic of experiments in ecology: Is pseudoreplication a pseudoissue? Oikos 94:27-38

Olsgard F, Schaanning MT, Widdicombe S, Kendall MA, Austen MC (2008) Effects of bottom trawling on ecosystem functioning. J Exp Mar Biol Ecol 366:123-133

Ouellette D, Desrosiers G, Gagne JP, Gilbert F, Poggiale JC, Blier PU, Stora G (2004) Effects of temperature on in vitro sediment reworking processes by a gallery biodiffusor, the polychaete Neanthes virens. Mar Ecol Prog Ser 266: 185-193

Pearson TH, Rosenberg R (1978) Macrobenthic succession in relation to organic enrichment and pollution of the marine environment. Oceanogr Mar Biol Annu Rev 16:229-311

R Development Core Team (2009) R: a language and environment for statistical computing. R Foundation for Statistical Computing, Viena, http://www.R-project.org

Rabaut M, Guilini K, Van Hoey G, Vincx M, Degraer S (2007) A bio-engineered soft-bottom environment: the impact of Lanice conchilega on the benthic species-specific densities and community structure. Estuar Coast Shelf Sci 75: 525-536

Rabaut M, Vincx M, Degraer S (2009) Do Lanice conchilega (sandmason) aggregations classify as reefs? Quantifying habitat modifying effects. Helgol Mar Res 63:37-46

Rhoads D, McCall P, Yingst J (1978) Disturbance and production on the estuarine seafloor. Am Sci 66:577-586

Rossi F, Gribsholt B, Middelburg JJ, Heip C (2008) Contextdependent effects of suspension feeding on intertidal ecosystem functioning. Mar Ecol Prog Ser 354:47-57

Schratzberger M, Whomersley P, Warr K, Bolam SG, Rees HL (2004) Colonisation of various types of sediment by estuarine nematodes via lateral infaunal migration: a laboratory study. Mar Biol 145:69-78

Sistermans WCH, Hummel H, Engelberts A, Markusse MM (2004) Inventarisatie macrofauna Westerschelde 2004: rapportage in het kader van de evaluatie van de verdieping van de Westerschelde. NI00/CEMO, Yerseke

Soetaert K, Herman PMJ, Middelburg JJ, Heip C, Smith CL, Tett P, Wild-Allen K (2001) Numerical modelling of the shelf break ecosystem: reproducing benthic and pelagic measurements. Deep-Sea Res II 48:3141-3177

Soetaert K, Van den Meersche K, van Oevelen D (2009) limSolve: Solving linear inverse models. $\mathrm{R}$ package version 1.5.1. http://CRAN.R-project.org/package=limSolve

$>$ Stocum ET, Plante CJ (2006) The effect of artificial defauna-

Editorial responsibility: Pei-Yuan Qian,

Kowloon, Hong Kong SAR tion on bacterial assemblages of intertidal sediments J Exp Mar Biol Ecol 337:147-158

Tengberg A, Almroth E, Hall P (2003) Resuspension and its effects on organic carbon recycling and nutrient exchange in coastal sediments: in situ measurements using new experimental technology. J Exp Mar Biol Ecol 285-286: 119-142

Thrush SF, Hewitt JE, Gibbs M, Lundquist C, Norkko A (2006) Functional role of large organisms in intertidal communities: community effects and ecosystem function. Ecosystems 9:1029-1040

Van Colen C, Montserrat F, Vincx M, Herman P, Ysebaert T, Degraer S (2008) Macrobenthic recovery from hypoxia in an estuarine tidal mudflat. Mar Ecol Prog Ser 372: $31-42$

Van Hoey G (2006) Spatio-temporal variability within the macrobenthic Abra alba community, with emphasis on the structuring role of Lanice conchilega. PhD thesis, Ghent University

> Van Hoey G, Degraer S, Vincx M (2004) Macrobenthic community structure of soft-bottom sediments at the Belgian Continental Shelf. Estuar Coast Shelf Sci 59:599-613

> Van Hoey G, Vincx M, Degraer S (2006) Some recommendations for an accurate estimation of Lanice conchilega density based on tube counts. Helgol Mar Res 60:317-321

van Oevelen D, Soetaert K, Franco MA, Moodley L, van Ijzerloo L, Vincx M, Vanaverbeke J (2009) Organic matter input and processing in two contrasting North Sea sediments: insights from stable isotope and biomass data. Mar Ecol Prog Ser 380:19-32

Vanaverbeke J, Franco M, van Oevelen D, Moodley L and others (2008) Benthic responses to sedimentation of phytoplankton on the Belgian Continental Shelf. In: Rousseau V, Lancelot C, Cox D (eds) Current status of eutrophication in the Belgian Coastal Zone. Presses Universitaires de Bruxelles, Brussels, p 73-90

Volkenborn N, Polerecky L, Hedtkamp SIC, van Beusekom JEE, de Beer D (2007) Bioturbation and bioirrigation extend the open exchange regions in permeable sediments. Limnol Oceanogr 52:1898-1909

Vopel K, Thistle D, Rosenberg R (2003) Effect of the brittle star Amphiura filiformis (Amphiuridae, Echinodermata) on oxygen flux into the sediment. Limnol Oceanogr 48: $2034-2045$

Wikander PB (1980) Quantitative aspects of deposit feeding in Abra nitida (Mueller) and A. longigallus (Scacchi) (Bivalvia, Tellinacea). Sarsia 66:35-48

Witte U, Wenzhofer F, Sommer S, Boetius A and others (2003) In situ experimental evidence of the fate of a phytodetritus pulse at the abyssal sea floor. Nature 424:763-766

Wright SW, Jeffrey SW (1997) High-resolution HPLC system for chlorophylls and carotenoids of marine phytoplankton. In: Jeffrey SW, Mantoura RFC, Wright SW (eds), Phytoplankton pigments in oceanography: guidelines to modern methods. UNESCO, Paris, p 327-341

Wright J, Jones C (2006) The concept of organisms as ecosystem engineers ten years on: progress, limitations, and challenges. Bioscience 56:203-209

Yingst JY, Rhoads DC (1980) The role of bioturbation in the enhancement of bacterial growth rates in marine sediments. In: Tenore K, Coull BC (eds) Marine benthic dynamics. Belle W. Baruch Library in Marine Science, University of South Carolina Press, Columbia, SC, p 407-421

Ziegelmeier E (1969) Neue Untersuchungen über die Wohnröhren-Bauweise von Lanice conchilega (Polychaeta, Sedentaria). Helgol Mar Res 19:216-229

Submitted: May 5, 2009; Accepted: September 26, 2009

Proofs received from author(s): January 20, 2010 